\section{Irrigation Scheduling of Kohlrabi (Brassica oleracea var. gongylodes) Using Crop Water Stress Index}

\author{
Maria Victoria Cremona, Hartmut Stützel ${ }^{1}$, and Henning Kage \\ Institute of Vegetable and Fruit Sciences, University of Hannover, D-30419 \\ Hannover, Germany
}

Additional index words. vegetable, drought, infrared thermometry, water use efficiency

\begin{abstract}
Two-year field experiments were carried out to evaluate the suitability of crop water stress index (CWSI) as a basis for irrigation scheduling of kohlrabi (Brassica oleracea L. var. gongylodes) by comparison with irrigation scheduling based on total soil water content (SWC). In the first year, irrigation scheduling when CWSI exceeded 0.3 resulted in more frequent water applications, but the total amount of irrigation water given was lower compared to irrigation when SWC fell below 70\%. Kohlrabi tuber fresh weight at harvest was similar in both scheduling treatments, leading to $25 \%$ higher irrigation water use efficiency in the CWSI-scheduled plots. In the second year, three threshold levels, i.e., 0.2 and $80 \%, 0.4$ and $60 \%$, and 0.6 and $40 \%$ of CWSI and SWC, respectively, were investigated. At the level of highest water supply $(\mathrm{CWSI}=0.2$ and $\mathrm{SWC}=80 \%)$, the total amount of water supplied was less in the CWSI but the number of irrigations was higher than in the SWC plots. The CWSI-based approach may be a method for irrigation scheduling of vegetables under temperate conditions. The higher irrigation frequency required would make this method particularly suitable in combination with irrigation system that allow frequent applications, i.e., in drip irrigation. To improve the method, a coupling with a soil water balance model seems promising.
\end{abstract}

Irrigation scheduling involves the definition of the time and amount of water application to a crop, according to a management objective (Howell, 1996). This definition can be based either on soil water balance methods, meteorological models that estimate crop evapotranspiration, or on measurements of plant parameters. The latter approach appears to be particularly attractive as plants integrate soil and meteorological variables in their response to water deficits (Jackson, 1982; Zipoli, 1990).

The relationship between leaf temperature and plant water status is well established (Alderfasi and Nielsen, 2001; Gupta et al., 2001; O'Toole et al., 1984) and increased temperatures are widely recognized as an early response to water limitations (Mahan et al., 2000). This is based on the fact that, in unstressed plants, transpiration cools leaves below ambient temperatures, while reduced transpiration rates raise leaf temperatures even above those of the surrounding air (Zipoli, 1990).

The use of infrared thermometry for the measurement of plant surface temperature has become very popular in the last decades as a fast, non-contact, and non-destructive method allowing the measurement of large samples with minimum interference (Hatfield, 1990).

Jackson et al. (1981) derived an equation from the radiation balance of the canopy that relates the difference of canopy temperature

\footnotetext{
Received for publication 21 June 2002. Accepted for publication 3 Apr. 2003. M.V. Cremona thanks the German Academic Exchange Service (DAAD) for fnancial support during this research.

${ }^{1}$ To whom reprint requests should be addressed. E-mail address: stuetzel@gem.uni-hannover.de
}

$\left(\mathrm{T}_{\mathrm{c}}\right)$ and air temperature $\left(\mathrm{T}_{\mathrm{a}}\right)$ to weather data:

$$
\begin{aligned}
\mathrm{T}_{\mathrm{c}}-\mathrm{T}_{\mathrm{a}}= & \frac{\mathrm{r}_{\mathrm{a}} \cdot \mathrm{R}_{\mathrm{n}}}{\rho \cdot \mathrm{c}_{\mathrm{p}}} \cdot \frac{\gamma\left(1+\mathrm{r}_{\mathrm{c}} / \mathrm{r}_{\mathrm{a}}\right)}{\Delta+\gamma\left(1+\mathrm{r}_{\mathrm{c}} / \mathrm{r}_{\mathrm{a}}\right)} \\
& -\frac{\mathrm{e}_{\mathrm{a}}^{*}-\mathrm{e}_{\mathrm{a}}}{\Delta+\gamma\left(1+\mathrm{r}_{\mathrm{c}} / \mathrm{r}_{\mathrm{a}}\right)}
\end{aligned}
$$

where $\mathrm{R}_{\mathrm{n}}$ is the net radiation $\left(\mathrm{W} \cdot \mathrm{m}^{-2}\right) ; \rho$ is the density of the air $\left(\mathrm{kg} \cdot \mathrm{m}^{-3}\right) ; \mathrm{c}_{\mathrm{p}}$ is the heat capacity of the air $\left(\mathrm{J} \cdot \mathrm{kg}^{-1} \cdot{ }^{\circ} \mathrm{C}^{-1}\right) ; \mathrm{e}_{\mathrm{a}}{ }^{*}-\mathrm{e}_{\mathrm{a}}$ is the vapor pressure deficit of the air $(\mathrm{Pa}) ; \gamma$ is the psychrometric constant $\left(\mathrm{Pa}^{\circ}{ }^{\circ} \mathrm{C}^{-1}\right) ; \mathrm{r}_{\mathrm{a}}$ and $\mathrm{r}_{\mathrm{c}}$ are the aerodynamic and canopy resistances to vapor transport $\left(\mathrm{s} \cdot \mathrm{m}^{-1}\right)$, respectively; and $\Delta$ is the slope of the saturation vapor pressure - temperature curve.

The upper limit of $T_{c}-T_{a}$ can be found from Eq. 1 by allowing the crop resistance $\left(\mathrm{r}_{\mathrm{c}}\right)$ to approach infinity $\left(\mathrm{r}_{\mathrm{c}} \rightarrow \infty\right)$ :

$$
\mathrm{T}_{\max }=\left(\mathrm{T}_{\mathrm{c}}-\mathrm{T}_{\mathrm{a}}\right)_{\max }=\frac{\mathrm{r}_{\mathrm{a}} \cdot \mathrm{R}_{\mathrm{n}}}{\rho \cdot \mathrm{c}_{\mathrm{p}}}
$$

This expression describes the maximum canopy-air temperature difference $\left(\mathrm{T}_{\mathrm{c}}-\mathrm{T}_{\mathrm{a}}\right)$ that can be expected under the given environmental conditions.

The lower limit of $T_{c}-T_{a}$ is found by setting $r_{c}=0$, i.e., assuming that plants act as a free water surface:

$$
\mathrm{T}_{\text {base }}=\left(\mathrm{T}_{\mathrm{c}}-\mathrm{T}_{\mathrm{a}}\right)_{\text {base }}=\frac{\mathrm{r}_{\mathrm{a}} \cdot \mathrm{R}_{\mathrm{n}}}{\rho \cdot \mathrm{c}_{\mathrm{p}}} \cdot \frac{\gamma}{\Delta+\gamma}-\frac{\mathrm{e}_{\mathrm{a}}^{*}-\mathrm{e}_{\mathrm{a}}}{\Delta+\gamma}
$$

With these two limits, a crop water stress index (CWSI) is defined:

$$
\text { CWSI }=\frac{\left(T_{c}-T_{a}\right)-T_{\text {base }}}{T_{\text {max }}-T_{\text {base }}}
$$

which should increase in the range between 0 and 1 with increasing water stress.
The CWSI approach was successfully used for irrigation scheduling in field crops like maize (Steele et al., 1997 and 2000) and wheat (Alderfasi and Nielsen, 2001) but no experiments are reported for vegetables. Several problems might limit its application for vegetables: the crop canopy structure is incomplete during a large proportion of the growing season causing interference of leaf temperature measurements with the soil background. Also, the presence of reproductive structures might lead to increased CWSI since those are typically non transpiring and can therefore be 3 to $5^{\circ} \mathrm{C}$ warmer than transpiring leaves (Hatfield, 1990).

Previous experiments have shown that CWSI calculated using temperatures of individual leaves was correlated to other parameters that express plant water stress under the local conditions at the experimental field of the Univ. of Hannover (Cremona, 2001). However, its potential usefulness for timing of irrigation in strategies that are intended to improve water use efficiency by reducing irrigation water volume without yield reduction needs further exploration in different climates (Stegman and Soderlund, 1992)

Responding to that need, the main objective of the present study was to test the accuracy of the CWSI in scheduling irrigation, particularly its ability to define the timing of irrigation in comparison to a standard irrigation scheduling method based on soil water content.

\section{Materials and Methods}

Two experiments were carried out in the experimental field of the Institute of Vegetable and Fruit Sciences, Univ. of Hannover, Germany, on a loamy sand soil (Hortic Anthrosol) under a mobile rain shelter. The latter was in its parking position adjacent to the experimental plots when it was not raining, and moved automatically to cover the plots when rain started. Thus, it provided control of the water supply to the plots. Irrigation was applied using a sprinkler system consisting from a nozzle bar moving at constant speed over the plots. Nozzles were spaced $50 \mathrm{~cm}$ apart. As a model vegetable crop, kohlrabi 'Logo' was chosen.

In 2000, seeds were sown on 19 June, plants were transplanted to the field on 24 July and irrigation treatments started on 17 Aug. The experiment consisted of 16 plots, $3 \mathrm{~m}$ long $\times$ $1.20 \mathrm{~m}$ wide, with 50 plants each (plant spacing $35 \times 35 \mathrm{~cm}$ ), but an early attack of cabbage maggot (Delia brassicae) caused the loss of some plots. Thus, irrigation treatments could be applied to only 12 plots, which were arranged in a completely randomized design with two irrigation treatments and six replications. Irrigation of six plots was scheduled according to total soil water content (SWC) and of the other six on the basis of crop water stress index (CWSI). The latter was calculated separately for each plot using Eq. 4. If the average of these plots had reached the threshold value of 0.3 , irrigation was applied at a quantity equal to the total evapotranspiration since the last irrigation, calculated as the sum of the daily products of reference evapotranspiration, $\mathrm{ET}_{\mathrm{o}}$, 
and crop factors $\mathrm{k}_{\mathrm{c}}$. $\mathrm{ET}_{\mathrm{o}}$ was calculated using the standard method of the German Weather Service (Haude, 1955). Depending on the canopy development, $\mathrm{k}_{\mathrm{c}}$ ranged between 0.7 and 1.05 (Allen et al., 1998). As the hourly data from the weather station could not be obtained before the day following the measurement, irrigation was applied early in the morning of the day following the measurements. In each of the six plots irrigated on the basis of soil moisture, SWC was measured using time domain reflectometry (TDR). Irrigation was applied when the average SWC had reached $70 \%$ of field capacity $(\mathrm{FC}=24 \% \mathrm{v} / \mathrm{v})$ at a quantity necessary to bring the soil up to $90 \%$ of FC. The SWC threshold level of $70 \%$ FC was chosen since this is common practice in vegetable production in temperate climates as it avoids yield reductions. The CWSI threshold of 0.30 was assumed to correspond to a soil water depletion of $30 \%$ (i.e., SWC of $70 \%$ FC), i.e. is also not yield limiting (Yazar et al., 1999).

TDR sensors $20 \mathrm{~cm}$ long were installed vertically in the middle of each plot to record soil moisture of the $0-20 \mathrm{~cm}$ layer daily with the TDR device (Soil Moisture Equipment Corp., Santa Barbara, Calif.). This depth was less than the entire root zone, but we expected the majority of the roots in the $0-20 \mathrm{~cm}$ zone. Canopy temperature measurements were taken in each plot with a portable infrared thermometer (Heitronics model KT 19.8), $\approx 1 \mathrm{~h}$ after solar noon (Idso et al., 1981) on at least four fully expanded leaves completely exposed to the sun. For each plot, the mean temperature of all measurements was considered in the CWSI calculations. At harvest on 4 Sept. the aerial parts of eight plants of four plots per treatment were cut, and tuber diameter, tuber fresh and dry weights, leaf fresh and dry weights, and leaf area were measured.

In 2001, seeds were sown on 25 Mar. and plants were transplanted to the field on 9 May. The experiment consisted of 18 plots, $3.3 \mathrm{~m}$ long $\times 2 \mathrm{~m}$ wide, each containing $\approx 70$ plants. Plots were arranged in a split-plot design with three blocks in the direction of the rain shelter movement. Main plots were the irrigation scheduling methods, i.e., SWC and CWSI, with tree threshold levels, i.e., CWSI values of $0.2,0.4,0.6$ and SWC values of $80 \%, 60 \%$, $40 \%$ of field capacity as subplots.

The treatments were applied as in 2000 but, for CWSI, scheduling $\mathrm{ET}_{\mathrm{o}}$ was estimated with the Penman-Monteith equation (Allen et al., 1998). TDR sensors 20 -cm long were installed vertically in the central area of each plot, one from the surface and another buried $20 \mathrm{~cm}$ deep, to monitor soil water status of the layers $0-20 \mathrm{~cm}$ and $20-40 \mathrm{~cm}$, respectively. In the SWC-scheduled plots, two sensors were installed in the surface layers. Average SWC provided by the surface TDR sensors was used for irrigation scheduling. Leaf temperature measurements were performed as in the previous experiment, but on eight fully expanded leaves, four facing north and the others south (Idso et al., 1986). Ten plants per plot were harvested.

In both experiments, the volume of wa-
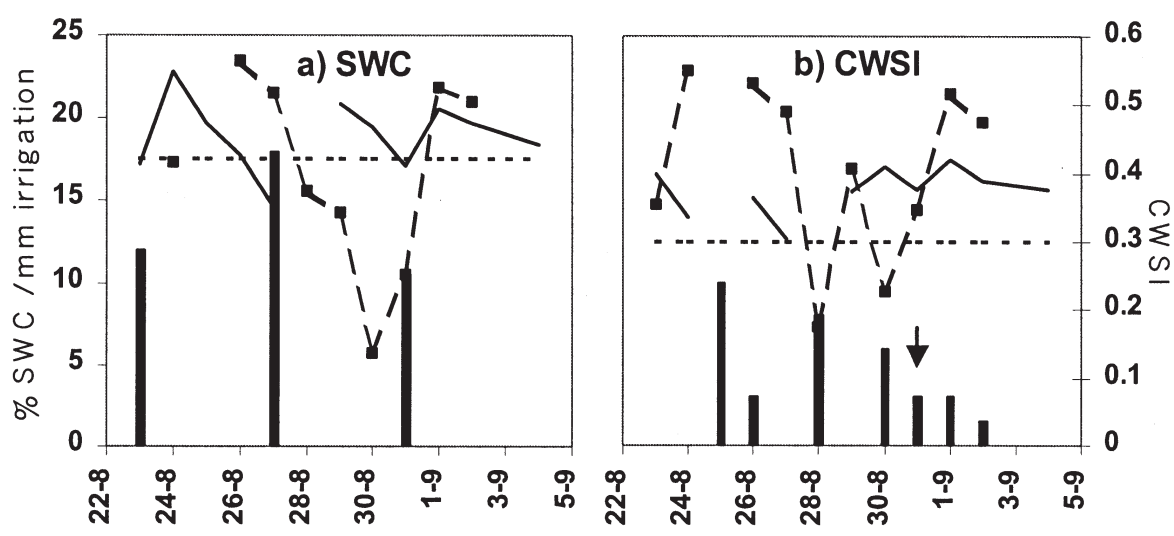

Fig. 1. Time course of SWC (\%, solid lines) and CWSI (broken lines) in plots irrigated based on (a) SWC and (b) CWSI in 2000. The vertical bars indicate the amount of irrigation water applied at each date $(\mathrm{mm})$, the dotted lines represent the thresholds for irrigation. The arrow indicates an erroneous irrigation (see text).

Table 1. Tuber and leaf weights and dimensions at final harvest in 2000 as dependent on irrigation scheduling method. Means over six replications (standard errors in parentheses).

\begin{tabular}{lcc}
\hline & CWSI $^{2}$ & SWC \\
\hline Tuber fresh wt (g/plant) & $534.3(182.6)$ & $502.1(179.3)$ \\
Tuber dry wt (g/plant) & $26.8(8.9)$ & $24.7(7.5)$ \\
Tuber diam (cm) & $10.9(1.8)$ & $10.6(1.3)$ \\
Leaf fresh wt (g/plant) & $189.6(63.9)$ & $170.5(54.6)$ \\
Leaf dry wt (g/plant) & $16.8(6.3)$ & $14.8(5.7)$ \\
Leaf area (cm²/plant) & $2565(761)$ & $2345(672)$ \\
\hline
\end{tabular}

${ }^{\mathrm{z}} \mathrm{CWSI}=$ crop water stress index; $\mathrm{SWC}=$ soil water content.

ter applied to each plot was recorded. Air temperature $\left(T_{a}\right)$, vapor pressure deficit $\left(e_{a}{ }^{*}\right.$ $\left.-\mathrm{e}_{\mathrm{a}}\right)$, global radiation $\left(\mathrm{R}_{\mathrm{g}}\right)$, and wind speed at $2 \mathrm{~m}$ were recorded simultaneously with an automatic weather station located $50 \mathrm{~m}$ away from the experimental area. Net radiation $\left(\mathrm{R}_{\mathrm{n}}\right)$ was estimated using the relationship (Feddes, 1971):

$$
R_{\mathrm{n}}=0.649 \mathrm{R}_{\mathrm{g}}-23
$$

Analyses of variance were performed for all data using SAS version 8.01 (SAS Institute, 1998). Upon significance of F-tests $(\alpha=0.05)$, mean comparisons were made using the Tukey test with $\alpha=0.05$.

\section{Results}

In 2000, scheduling through CWSI required smaller and more frequent applications than the SWC scheduling (Fig. 1). The total quantity of water used to irrigate according to CWSI was less than the quantity used for the SWC-scheduled plots, i.e., 34.5 vs. $40.5 \mathrm{~mm}$. Moreover, one irrigation in the CWSI plots was applied erroneously due to a calculation error (arrow in Fig. 1) and could have been saved. Both treatments resulted in similar final fresh and dry weights of tubers and leaves, tuber diameters, and leaf areas (Table 1). In consequence, the irrigation use efficiency with respect to tuber fresh weight tended to be higher in plots scheduled with CWSI than in the SWC treatment.

In 2001, when three threshold levels for each irrigation scheduling method were tested, only the third (CWSI $=0.6$ and $60 \%$ FC) resulted in a reduction of fresh weights and organ sizes (Table 2). Dry weights were not significantly different among the treatments. No differences could be detected between the higher (CWSI $=0.2$ and $80 \%$ FC) and the intermediate level $(\mathrm{CWSI}=0.4$ and $60 \% \mathrm{FC})$ within each scheduling method and between methods within each threshold level. As in the previous experiment, irrigations were generally more frequent and individual applications were smaller under CWSI scheduling on the first level (Fig. 2). However, these differences decreased as threshold levels were raised. Total amounts of water applied were similar in both scheduling methods within the same threshold levels. In comparison to levels 1 and 2, lower amounts of irrigation water were applied on the third level of both scheduling methods. This difference could have been even higher, but on 15 June the rain-shelter failed in protecting the crop area, so that the crops were given 4.3 $\mathrm{mm}$ of natural rainfall, which would not have been required according to the SWC and CWSI values determined. The relationship between tuber fresh yield and the amount of irrigation water applied characterizes the irrigation water use efficiency (Fig. 3). There seems to be a slight tendency towards reduced efficiencies with increasing levels of irrigation, but data are too few to calculate meaningful nonlinear regressions. The data of both irrigation scheduling methods showed similar trends, with a slight tendency towards higher irrigation water use efficiencies in the CSWI compared to the SWC treatments. 
Table 2. Leaf area, fresh and dry weights, tuber diameter, dry and fresh weights, and number of leaves at harvest of kohlrabi plants irrigated according to three thresholds of crop water stress index (CWSI) and soil water content (SWC). Means and standard differences (s.d.) of three replications.

\begin{tabular}{|c|c|c|c|c|c|c|c|}
\hline & & & $\begin{array}{c}\text { CWSI } \\
\text { Threshold }\end{array}$ & & & $\begin{array}{l}\text { SWC } \\
\text { hreshold }\end{array}$ & \\
\hline & & 0.2 & 0.4 & 0.6 & $80 \% \mathrm{FC}$ & $60 \% \mathrm{FC}$ & $40 \% \mathrm{FC}$ \\
\hline $\begin{array}{l}\text { Leaf area } \\
\left(\mathrm{cm}^{2} / \text { plant }\right)\end{array}$ & $\begin{array}{l}\text { Mean } \\
\text { s.d. }\end{array}$ & $\begin{array}{c}2940 \mathrm{a}^{\mathrm{z}} \\
731\end{array}$ & $\begin{array}{c}2742 \mathrm{a} \\
564\end{array}$ & $\begin{array}{c}2322 \mathrm{~b} \\
538\end{array}$ & $\begin{array}{c}2791 \mathrm{a} \\
496\end{array}$ & $\begin{array}{c}2933 \mathrm{a} \\
635\end{array}$ & $\begin{array}{c}2169 \mathrm{~b} \\
431\end{array}$ \\
\hline $\begin{array}{l}\text { Leaf fresh wt } \\
\text { (g/plant) }\end{array}$ & $\begin{array}{l}\text { Mean } \\
\text { sd }\end{array}$ & $\begin{array}{c}239 a \\
63\end{array}$ & $\begin{array}{c}215 \mathrm{a} \\
53\end{array}$ & $\begin{array}{c}173 \mathrm{~b} \\
46\end{array}$ & $\begin{array}{c}220 \mathrm{a} \\
47\end{array}$ & $\begin{array}{c}218 \mathrm{a} \\
42\end{array}$ & $\begin{array}{c}162 \mathrm{~b} \\
36\end{array}$ \\
\hline $\begin{array}{l}\text { Leaf dry wt } \\
\text { (g/plant) }\end{array}$ & $\begin{array}{l}\text { Mean } \\
\text { s.d. }\end{array}$ & $\begin{array}{c}20.7 \mathrm{a} \\
6.4\end{array}$ & $\begin{array}{c}20.8 \mathrm{a} \\
7.2\end{array}$ & $\begin{array}{c}19.1 \mathrm{a} \\
5.2\end{array}$ & $\begin{array}{c}21.2 \mathrm{a} \\
5.7\end{array}$ & $\begin{array}{c}20.0 \mathrm{a} \\
5.1\end{array}$ & $\begin{array}{c}18.2 \mathrm{a} \\
5.3\end{array}$ \\
\hline $\begin{array}{l}\text { Tuber diam } \\
(\mathrm{cm})\end{array}$ & $\begin{array}{l}\text { Mean } \\
\text { s.d. }\end{array}$ & $\begin{array}{r}10 \mathrm{a} \\
1.0\end{array}$ & $\begin{array}{r}10 \mathrm{a} \\
1.1\end{array}$ & $\begin{array}{l}9 \mathrm{~b} \\
1.0\end{array}$ & $\begin{array}{r}10 \mathrm{a} \\
0.8\end{array}$ & $\begin{array}{r}10 \mathrm{a} \\
0.7\end{array}$ & $\begin{array}{l}9 \mathrm{~b} \\
0.7\end{array}$ \\
\hline $\begin{array}{l}\text { Tuber fresh wt } \\
\text { (g/plant) }\end{array}$ & $\begin{array}{l}\text { Mean } \\
\text { s.d. }\end{array}$ & $\begin{array}{l}404 \mathrm{a} \\
112\end{array}$ & $\begin{array}{l}386 \mathrm{a} \\
120\end{array}$ & $\begin{array}{c}298 \mathrm{~b} \\
97\end{array}$ & $\begin{array}{c}368 \mathrm{a} \\
82\end{array}$ & $\begin{array}{c}394 \mathrm{a} \\
79\end{array}$ & $\begin{array}{c}268 \mathrm{~b} \\
58\end{array}$ \\
\hline $\begin{array}{l}\text { Tuber dry wt } \\
\text { (g/plant) }\end{array}$ & $\begin{array}{l}\text { Mean } \\
\text { s.d. }\end{array}$ & $\begin{array}{c}21.1 \mathrm{a} \\
4.7\end{array}$ & $\begin{array}{c}19.5 \mathrm{a} \\
3.3\end{array}$ & $\begin{array}{c}19.1 \mathrm{a} \\
5.1\end{array}$ & $\begin{array}{c}19.2 \mathrm{a} \\
3.5\end{array}$ & $\begin{array}{c}20.5 \mathrm{a} \\
5.2\end{array}$ & $\begin{array}{c}18.7 \mathrm{a} \\
3.2\end{array}$ \\
\hline $\begin{array}{l}\text { No. of leaves } \\
\text { (plant) }\end{array}$ & $\begin{array}{l}\text { Mean } \\
\text { s.d. }\end{array}$ & $\begin{array}{r}15 \mathrm{a} \\
2.6\end{array}$ & $\begin{array}{l}15 \mathrm{a} \\
2.2\end{array}$ & $\begin{array}{l}14 \mathrm{~b} \\
2.0\end{array}$ & $\begin{array}{c}15 \mathrm{a} \\
2.4\end{array}$ & $\begin{array}{r}15 \mathrm{a} \\
2.7\end{array}$ & $\begin{array}{c}14 \mathrm{ab} \\
2.1\end{array}$ \\
\hline
\end{tabular}

${ }^{\mathrm{z}}$ Means followed by the same letters were not significantly different $(P<0.05)$
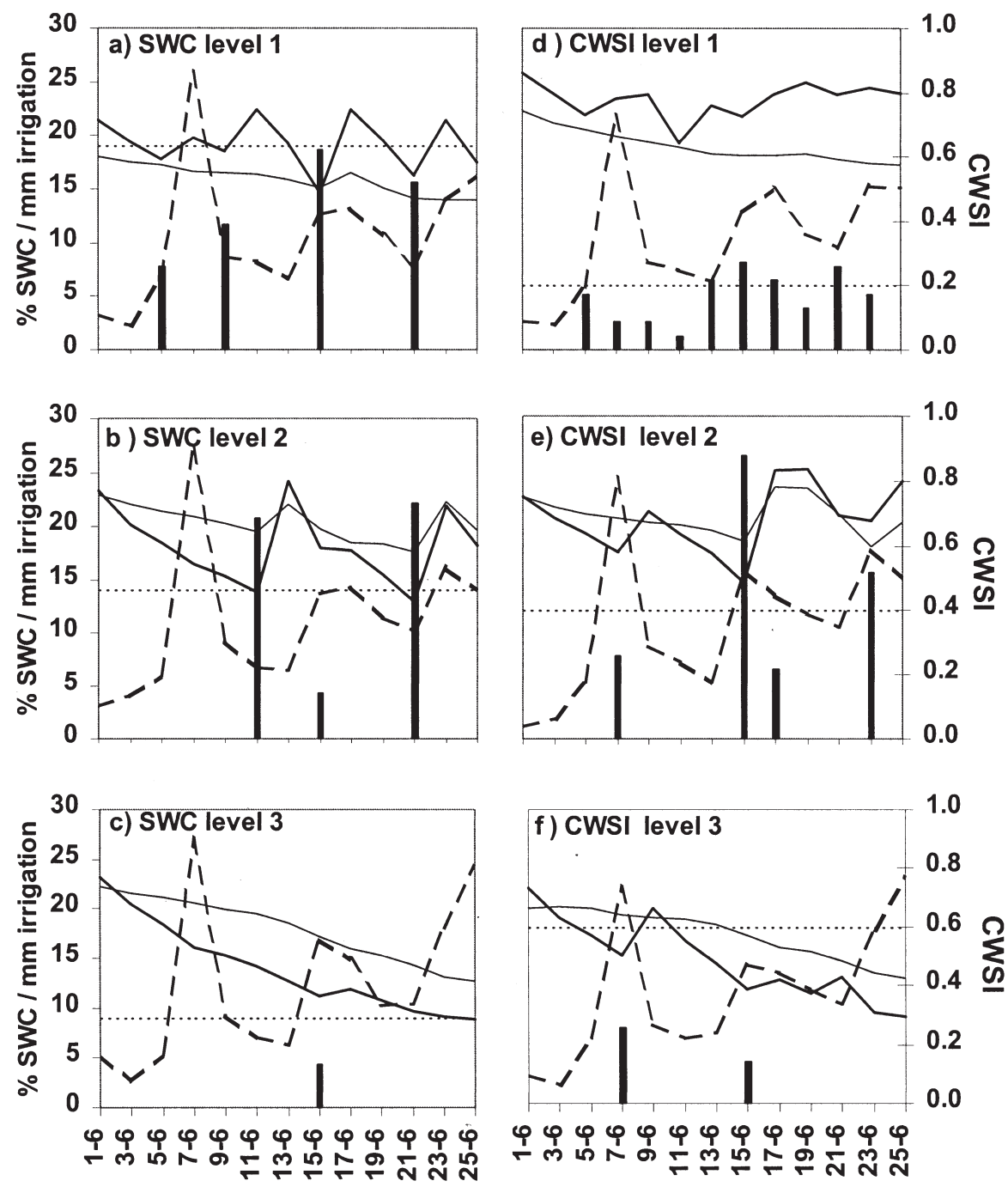

Fig. 2. Time course of SWC in 0-20 cm (\%, thick solid lines) and $20-40 \mathrm{~cm}$ (\%, thin solid lines), as well as CWSI (broken lines) in plots irrigated based on (a, b, c) SWC and (d, e, f) CWSI in 2001. The vertical bars indicate the amount of irrigation water applied at each date (mm), except 15 June (15-6) (see text), the dotted lines represent the thresholds for irrigation.

\section{Discussion}

The objective of this study was to test the usefulness of the crop water stress index as a tool for irrigation scheduling in a vegetable crop. In two field experiments with kohlrabi at Hannover, Germany, timing of irrigation with CWSI was compared to timing based on SWC.

CWSI was already shown to be useful for monitoring the water stress of corn in a Mediterranean climate by Irmak et al. (2000), and of cotton in a semiarid area (Pinter and Reginato, 1982). In the first experiment reported here, the CWSI-based method resulted in lower irrigation requirements than an irrigation scheduling based on soil water content, to reach the same yield level. In the second year, irrigation water use efficiency tended to be slightly higher in the CWSI-scheduled treatments, which also received more frequent water applications. Similar results were reported by Wanjura et al. (1992) when testing a canopy temperature value as an indicator of plant water needs in cotton irrigated automatically with a drip system. In a comparison of several irrigation scheduling methods for corn, CWSI-scheduled treatments required more irrigation than those based on soil water content (Steele et al., 2000). In some early studies (Steele et al., 1997), difficulties in implementing CWSI measurements as a sole criterion to schedule corn irrigation were reported to have been due to the environmental variability prevailing in the experimental area.

To define the optimal CWSI to be used in irrigation scheduling of kohlrabi, different threshold levels of the index were used and compared to different levels of soil water content in the second experiment. For maize, yield reductions were reported minimal when threshold values were below 0.33 (Yazar et al., 1999) and 0.4 (Steele et al., 1997). In our study, a CWSI threshold of 0.4 did not result in a significant reduction in kohlrabi tuber yield. Although it is very likely that the optimal threshold value depends highly on the crop and local environmental conditions, it can be concluded that the results of this study lie well within the range of published values (Irmak et al, 2000; Jackson, 1982; Stegman and Soderlund, 1992).

When the threshold level of the CWSI index was increased from 0.2 to 0.4 in the second experiment, a tendency toward increased irrigation needs and lower irrigation water use efficiency was observed. The higher the threshold, the less frequent were the irrigation events, which resulted in one case in the application of more than $25 \mathrm{~mm}$. The distribution of this high amount of water in the soil by drip irrigation was not homogeneous, so that water losses due to percolation below the rooting zone were likely. It has been suggested before that the infrared temperature-based indices are more likely to be suitable for early detection of water shortage than soil-based methods (Stanghellini and De Lorenzi, 1994). In the light of the findings of the present study, it can therefore be concluded that CWSI is particularly suitable for irrigation scheduling when frequent and small 


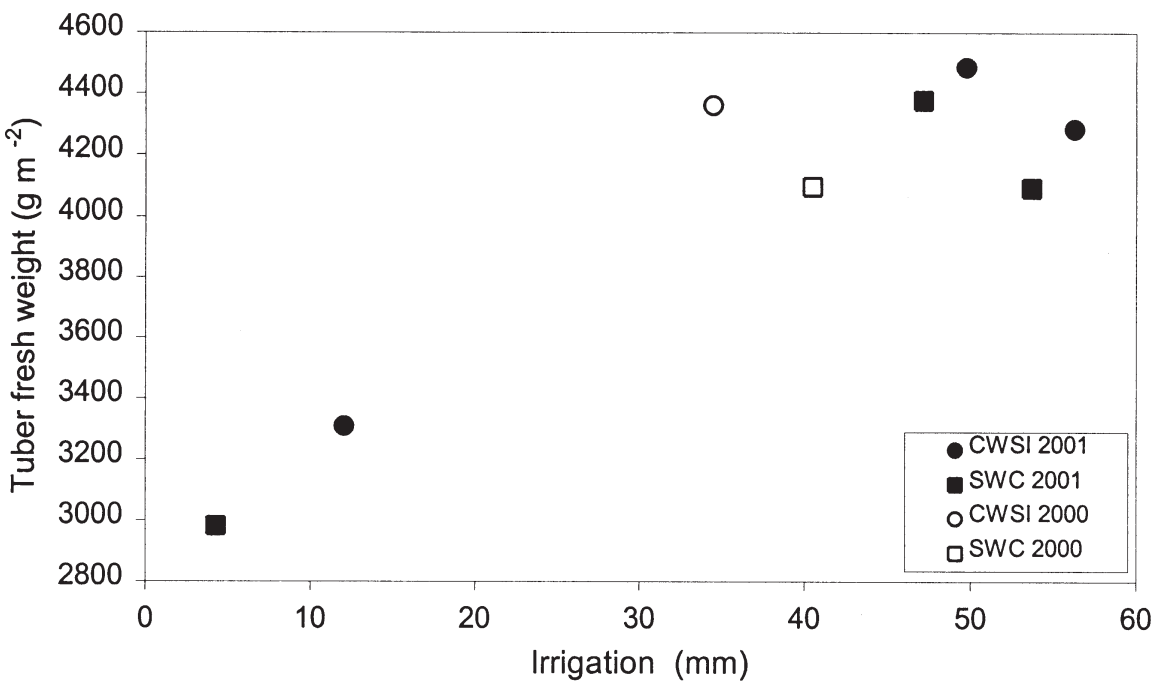

Fig. 3. Relationship between tuber fresh weight and irrigation water applied to kohlrabi crops irrigated according to CWSI or SWC in 2 years.

irrigation amounts can be applied, i.e., in drip irrigation. To avoid applications that exceed the soil field capacity, CWSI should be combined with a model of soil water balance.

An important feature observed in our experiments is that CWSI did not always recover after irrigation was applied, as was expected (Jackson et al., 1981). This could be a result of the variable weather conditions that prevailed during the experiments, and is consistent with the results obtained in other experiments (Cremona et al., 2001) where low seasonal correlations of CWSI with the soil water content were shown. In the experiments reported here, this fact did not interfere with the irrigation management decisions, but could be a limitation of the methodology in other crops or weather conditions.

In summary, CWSI-scheduled irrigation was at least equal to the conventional SWCbased irrigation with respect to yield and water use efficiency, even in a temperate humid climate with variable weather conditions as in northern Germany. Nevertheless, bearing in mind the variability of CWSI under unstable weather conditions, and the inability of the method to provide information about the quantity of water to apply, it would be desirable to combine CWSI measurements with modeling of soil water balance to design a more accurate irrigation-scheduling technique.

\section{Literature Cited}

Alderfasi, A.A. and D.C. Nielsen. 2001. Use of crop water stress index for monitoring water status and scheduling irrigation in wheat. Agr. Water Mgt. 47:69-75.

Allen, R.G., L.S. Pereira, D. Raes, and M. Smith 1998. Crop evapotranspiration. Guidelines for computing crop water requirements. FAO Irr. and Drainage Papers No. 56. FAO Rome.

Cremona, M.V.2001. The use of canopy temperature to optimise irrigation in vegetable crops. MSc Thesis, Univ. of Hannover, Faculty of Hort. Hannover, Germany.

Feddes, R.A. 1971. Water, heat and crop growth. PhD Diss., Agr. Univ. Wageningen 71-12:184.

Gupta, N.K., S. Gupta, and A. Kumar. 2001. Effect of water stress on physiological attributes and their relationships with growth and yield of wheat cultivars at different stages. J. Agron. Crop Sci. 186:55-62

Hatfield, J.L. 1990. Measuring plant water stress with an infrared thermometer. HortScience 25:1535-1538.

Haude, W. 1955. Zur Bestimmung der Verdunstung auf möglichst einfache Weise.-Mitt. Dt. Wetterd. $11: 1-24$

Howell, T.A. 1996. Irrigation scheduling research and its impact on water use, p. 21-33. In: C.R Camp, E.J. Sadler, and R.E. Yoder (eds.). Evapotranspiration and irrigation scheduling. Proc. Intl. Conf., Amer. Soc. Agr. Eng., San Antonio, Texas.

Idso, S.B., R.D. Jackson, P.J. Pinter Jr., R.J. Regi- nato, and J.L. Hatfield. 1981. Normalizing the stress-degree-day parameter for environmental variability. Agr. Meteorol. 24:45-55.

Idso, S.B., K.L. Clawson and M.L. Anderson. 1986 Foliage temperature: Effects of environmental factors with implications for plant water stress assessment and the $\mathrm{CO}_{2} /$ climate connection. Water Resources Res. 22:1702-1716.

Irmak, S., D. Haman, and R. Bastug. 2000. Determination of crop water stress index for irrigation timing and yield estimation of corn. Agron. J. 92:1220-1227.

Jackson, R.D. 1982. Canopy temperature and crop water stress, p. 43-85. In: D.I. Hillel (ed.). Advances in irrigation. Academic Press.

Jackson, R.D., S.B. Idso, R.J. Reginato, and P.J. Pinter Jr. 1981. Canopy temperature as a crop water stress indicator. Water Resources Res. 17:1133-1138.

Mahan, J.R., J.J. Burke, D.R. Updurch, and D.F Wanjura. 2000. Irrigation scheduling using biological-based optimal temperature and continuous monitoring of canopy temperature. Acta Hort. 537:375-381.

O’Toole, J.C., N.C. Turner, O.P. Namuco, M. Dingkuhn, and K.A. Gomez. 1984. Comparison of some crop water stress measurement methods. Crop Sci. 24:1121-1128.

Pinter, P.J. and R.J. Reginato. 1982. A thermal infrared technique for monitoring cotton water stress and scheduling irrigations. Transact. Amer. Soc. Agr. Eng. 25:1651-1665.

SAS Institute. 1998. SAS/STAT user's guide. Release 6.03 ed. SAS Inst., Cary, N.C.

Stanghellini, C. and F. De Lorenzi. 1994. A comparison of soil and canopy temperaturebased methods for the early detection of water stress in a simulated patch of pasture. Irr. Sci. 14:141-146.

Steele, D.D, B.L. Gregor, and J.B. Shae. 1997. Irrigation scheduling method for popcorn in the northern Great Plains. Transact. Amer. Soc. Agr Eng. 40:149-155.

Steele, D.D.,E.C. Stegman, and R.E. Knighton. 2000 Irrigation management for corn in the northern Great Plains, USA. Irr. Sci. 19:107-114.

Stegman, E.C. and M. Soderlund. 1992. Irrigation scheduling of spring wheat using infrared thermometry. Transact. Amer. Soc. Agr. Eng. 35:143-152.

Wanjura, D.F., D.R. Upchurch, and J.R. Mahan. 1992. Automated irrigation based on threshold canopy temperature. Transact. Amer. Soc. Agr. Eng. 35:153-159.

Yazar, A., T.A. Howell, D.A. Dusek, and K.S. Copeland. 1999. Evaluation of crop water stress index for LEPA irrigated corn. Irr. Sci. 18:171-180.

Zipoli, G. 1990. Remote sensing for scheduling irrigation: A review of thermal infrared approach. Acta Hort. 278:281-288. 